\title{
Front Matter: Volume 8962
}

, "Front Matter: Volume 8962," Proc. SPIE 8962, High Energy/Average Power Lasers and Intense Beam Applications VII, 896201 (20 March 2014); doi: $10.1117 / 12.2062795$

SPIE. Event: SPIE LASE, 2014, San Francisco, California, United States 


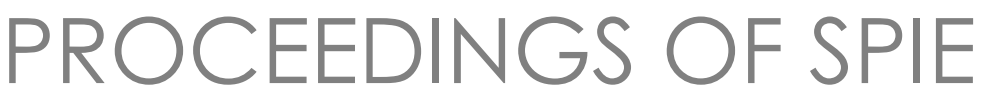

\section{High Energy/Average Power Lasers and Intense Beam Applications VII}

Steven J. Davis

Michael C. Heaven

J. Thomas Schriempf

Editors

2 and 4 February 2014

San Francisco, California, United States

Sponsored and Published by

SPIE 
The papers included in this volume were part of the technical conference cited on the cover and title page. Papers were selected and subject to review by the editors and conference program committee. Some conference presentations may not be available for publication. The papers published in these proceedings reflect the work and thoughts of the authors and are published herein as submitted. The publisher is not responsible for the validity of the information or for any outcomes resulting from reliance thereon.

Please use the following format to cite material from this book:

Author(s), "Title of Paper," in High Energy/Average Power Lasers and Intense Beam Applications VII, edited by Steven J. Davis, Michael C. Heaven, J. Thomas Schriempf, Proceedings of SPIE Vol. 8962 (SPIE, Bellingham, WA, 2014) Article CID Number.

ISSN: 0277-786X

ISBN: 9780819498755

Published by

SPIE

P.O. Box 10, Bellingham, Washington 98227-0010 USA

Telephone +1 3606763290 (Pacific Time) · Fax +1 3606471445

SPIE.org

Copyright @ 2014, Society of Photo-Optical Instrumentation Engineers.

Copying of material in this book for internal or personal use, or for the internal or personal use of specific clients, beyond the fair use provisions granted by the U.S. Copyright Law is authorized by SPIE subject to payment of copying fees. The Transactional Reporting Service base fee for this volume is $\$ 18.00$ per article (or portion thereof), which should be paid directly to the Copyright Clearance Center (CCC), 222 Rosewood Drive, Danvers, MA 01923. Payment may also be made electronically through CCC Online at copyright.com. Other copying for republication, resale, advertising or promotion, or any form of systematic or multiple reproduction of any material in this book is prohibited except with permission in writing from the publisher. The CCC fee code is 0277-786X/14/\$18.00.

Printed in the United States of America.

Publication of record for individual papers is online in the SPIE Digital Library.

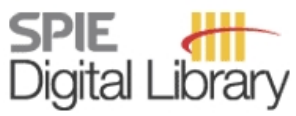

SPIEDigitallibrary.org

Paper Numbering: Proceedings of SPIE follow an e-First publication model, with papers published first online and then in print and on CD-ROM. Papers are published as they are submitted and meet publication criteria. A unique, consistent, permanent citation identifier (CID) number is assigned to each article at the time of the first publication. Utilization of CIDs allows articles to be fully citable as soon as they are published online, and connects the same identifier to all online, print, and electronic versions of the publication. SPIE uses

a six-digit CID article numbering system in which:

- The first four digits correspond to the SPIE volume number.

- The last two digits indicate publication order within the volume using a Base 36 numbering

system employing both numerals and letters. These two-number sets start with 00, 01, 02, 03, 04, $05,06,07,08,09,0 A, 0 B \ldots$. 0Z, followed by 10-1Z, 20-2Z, etc.

The CID Number appears on each page of the manuscript. The complete citation is used on the first page, and an abbreviated version on subsequent pages. Numbers in the index correspond to the last two digits of the six-digit CID Number. 


\section{Contents}

vii Conference Committee
ix Introduction

\section{SESSION 1 OPTICALLY PUMPED RARE GAS LASERS}

896202 Kinetics of an optically pumped metastable Ar laser (Invited Paper) [8962-1]

J. Han, M. C. Heaven, Emory Univ. (United States); G. D. Hager, Air Force Institute of Technology (United States); G. B. Venus, L. B. Glebov, CREOL, The College of Optics and Photonics, Univ. of Central Florida (United States)

896203 Laser excitation dynamics of argon metastables generated in atmospheric pressure flows by microwave frequency microplasma arrays [8962-2]

W. T. Rawlins, K. L. Galbally-Kinney, S. J. Davis, Physical Sciences Inc. (United States);

A. R. Hoskinson, J. A. Hopwood, Tufts Univ. (United States)

\section{SESSION 2 DPAL I}

896205 Experimental study of the diode pumped alkali laser (DPAL) (Invited Paper) [8962-4] M. Endo, Tokai Univ. (Japan); R. Nagaoka, H. Nagaoka, T. Nagai, F. Wani, Kawasaki Heavy Industries, Ltd. (Japan)

896206 Multi-quantum excitation in optically pumped alkali atom: rare gas mixtures [8962-5] K. L. Galbally-Kinney, W. T. Rawlins, S. J. Davis, Physical Sciences Inc. (United States)

896207 The role of adiabaticity in alkali atom fine-structure mixing [8962-6]

B. Eshel, D. E. Weeks, G. P. Perram, Air Force Institute of Technology (United States)

896208 An experimental high pressure line shape study of the rubidium $D_{1}$ and $D_{2}$ transitions with the noble gases, methane, and ethane [8962-7]

G. A. Pitz, Air Force Research Lab. (United States); G. D. Hager, Air Force Institute of Technology (United States); T. B. Tafoya, J. W. Young, Air Force Research Lab. (United States); G. P. Perram, Air Force Institute of Technology (United States); D. A. Hostutler, Air Force Research Lab. (United States)

896209 Semi-analytical and 3D CFD DPAL modeling: feasibility of supersonic operation (Invited Paper) [8962-8]

S. Rosenwaks, B. D. Barmashenko, K. Waichman, Ben-Gurion Univ. of the Negev (Israel) 
8962 OB Simulation of deleterious processes in a static-cell diode pumped alkali laser [8962-10] B. Q. Oliker, Ball Aerospace \& Technologies Corp. (United States); J. D. Haiducek, Univ. of Michigan (United States); D. A. Hostutler, G. A. Pitz, Air Force Research Lab. (United States); W. Rudolph, The Univ. of New Mexico (United States); T. J. Madden, Air Force Research Lab. (United States)

8962 OC Kinetic and fluid dynamic processes in diode pumped alkali lasers: semi-analytical and 2D and 3D CFD modeling [8962-11]

B. D. Barmashenko, S. Rosenwaks, K. Waichman, Ben-Gurion Univ. of the Negev (Israel)

8962 OD Mechanisms for plasma formation during high power pumping of XPAL [8962-12]

N. Yu. Babaeva, Univ. of Michigan (United States); O. Zatsarinny, Drake Univ. (United

States); K. Bartschat, Drake Univ. (United States) and Harvard-Smithsonian Ctr. for

Astrophysics (United States); M. J. Kushner, Univ. of Michigan (United States)

SESSION 4 DPAL III

8962 OE Scalable pump source for diode pumped alkali laser [8962-13]

F. W. Hersman, The Univ. of New Hampshire (United States) and Xemed LLC (United States);

J. H. Distelbrink, J. Ketel, D. Sargent, D. W. Watt, Xemed LLC (United States)

8962 OF Narrow line diode laser stacks for DPAL pumping [8962-14]

T. Koenning, D. Irwin, D. Stapleton, R. Pandey, T. Guiney, S. Patterson, DILAS Diode Laser, Inc. (United States)

$89620 \mathrm{O}$ Oxygen atom density and thermal energy control in an electric-oxygen iodine laser [8962-15]

G. F. Benavides, CU Aerospace LLC (United States) and Univ. of Illinois at UrbanaChampaign (United States); A. D. Palla, CU Aerospace LLC (United States);

J. W. Zimmerman, CU Aerospace LLC (United States) and Univ. of Illinois at UrbanaChampaign (United States); B. S. Woodard, Univ. of Illinois at Urbana-Champaign (United States); D. L. Carroll, CU Aerospace LLC (United States); W. C. Solomon, Univ. of Illinois at Urbana-Champaign (United States)

\section{SESSION 5 OTHER HIGH POWER LASERS AND APPLICATIONS}

8962 OI ELI-beamlines: extreme light infrastructure science and technology with ultra-intense lasers [8962-17]

B. Le Garrec, S. Sebban, D. Margarone, M. Precek, S. Weber, O. Klimo, G. Korn, B. Rus, Institute of Physics of the ASCR, v.v.i. (Czech Republic)

POSTER SESSION

8962 OK Recent advances for temporal and spectral diagnostics of the LMJ front-end laser facility [8962-19]

J.-F. Gleyze, V. Moreau, J. Dubertrand, J. Luce, CEA, CESTA (France)

iv 
$8962 \mathrm{OL} \quad$ Near field angular filtering with volume Bragg gratings in photothermorefractive glass [8962-20]

X. Zhang, F. Gao, J. Feng, K. Zou, X. Yuan, Soochow Univ. (China)

$89620 \mathrm{M}$ High contrast research in the Nd:glass laser system based on optical parametric amplification temporal cleaning device [8962-21]

X. Lu, Tongji Univ. (China) and Shanghai Institute of Optics and Fine Mechanics (China);

Y. Leng, Shanghai Institute of Optics and Fine Mechanics (China) and Tongji Univ. (China);

Z. Sui, China Academy of Engineering Physics (China); Y. Li, Z. Zhang, Y. XU, X. Guo, Y. Liu,

R. Li, Z. XU, Shanghai Institute of Optics and Fine Mechanics (China)

$89620 \mathrm{~N}$ A single-filament schlieren method for flowing characteristic measurements in the pulsed gas lasers [8962-22]

Y. XU, D. Zuo, X. Wang, B. Li, A. YU, S. Luo, Huazhong Univ. of Science and Technology (China)

Author Index 
Proc. of SPIE Vol. $8962896201-6$

Downloaded From: https://www.spiedigitallibrary.org/conference-proceedings-of-spie on 25 Apr 2023 Terms of Use: https://www.spiedigitallibrary.org/terms-of-use 


\title{
Conference Committee
}

\author{
Symposium Chairs
}

Bo Gu, Bos Photonics (United States)

Andreas Tünnermann, Fraunhofer-Institut für Angewandte Optik und Feinmechanik (Germany) and Friedrich-Schiller-Universität Jena (Germany)

Symposium Co-Chairs

Guido Hennig, Daetwyler Graphics AG (Swtizerland)

Yongfeng Lu, University of Nebraska-Lincoln (United States)

Program Track Chair

Gregory J. Quarles, Optoelectronics Management Network (United States)

Conference Chairs

Steven J. Davis, Physical Sciences Inc. (United States)

Michael C. Heaven, Emory University (United States)

J. Thomas Schriempf, Naval Sea Systems Command (United States)

Conference Program Committee

David L. Carroll, CU Aerospace LLC (United States)

Jarmila Kodymová, Institute of Physics of the ASCR, v.v.i. (Czech Republic)

Timothy Madden, Air Force Research Laboratory (United States)

William E. McDermott, University of Denver (United States)

Wilson T. Rawlins, Physical Sciences Inc. (United States)

\section{Session Chairs}

1 Optically Pumped Rare Gas Lasers

Steven J. Davis, Physical Sciences Inc. (United States)

2 DPAL I

Michael C. Heaven, Emory University (United States)

3 DPAL II

Wilson T. Rawlins, Physical Sciences Inc. (United States) 
4 DPAL III

David L. Carroll, CU Aerospace LLC (United States)

5 Other High Power Lasers and Applications

Steven J. Davis, Physical Sciences Inc. (United States) 


\title{
Introduction
}

We had a very full and productive conference with a good mix of papers and several international speakers. The Conference focused on gas-phase lasers and some high power laser interactions. We began with a short informal session that summarized the history of gas lasers over the last 50 years. That was followed by several papers that described a new class of gas lasers: Optically Pumped Rare Gas Lasers. This new approach complements the rapidly growing area of Diode Laser Pumped Alkali Lasers known as DPAL that was first announced at our meeting in 2003. DPAL was well represented as this system continues to develop. We believe that both these systems have potential for high power scaling and applications. We also had presentations that described advances in narrow band diode lasers that can serve as excitation sources for DPAL and perhaps the rare gas systems. Another relatively new gas laser, the Electric Oxygen lodine Laser was also discussed. Finally, several papers were presented that described novel applications of high power lasers: One of these discussed the design and ongoing construction of an ultra-high power laser facility in Prague that will be available for researchers from around the world. The laser sources at this facility will be available for basic laser physics and laser materials interactions including biological studies.

In summary, we were very pleased with the program and the attendance. The discussions at the sessions were very productive, and we look forward to future conferences.

\author{
Steven J. Davis \\ Michael C. Heaven \\ J. Thomas Schriempf
}


Proc. of SPIE Vol. $8962896201-10$

Downloaded From: https://www.spiedigitallibrary.org/conference-proceedings-of-spie on 25 Apr 2023 Terms of Use: https://www.spiedigitallibrary.org/terms-of-use 